\title{
GCU
}

Glasgow Caledonian

University

University for the Common Good

\section{Skill shortage of bricklayers in Scotland}

Lawani, Kenneth; McKenzie-Govan, Sarah; Hare, Billy; Sherratt, Fred; Cameron, lain

Published in:

Journal of Engineering, Design and Technology

DOI:

10.1108/JEDT-12-2020-0503

Publication date:

2022

Document Version

Author accepted manuscript

Link to publication in ResearchOnline

Citation for published version (Harvard):

Lawani, K, McKenzie-Govan, S, Hare, B, Sherratt, F \& Cameron, I 2022, 'Skill shortage of bricklayers in Scotland', Journal of Engineering, Design and Technology, vol. 20, no. 1, pp. 321-338.

https://doi.org/10.1108/JEDT-12-2020-0503

\section{General rights}

Copyright and moral rights for the publications made accessible in the public portal are retained by the authors and/or other copyright owners and it is a condition of accessing publications that users recognise and abide by the legal requirements associated with these rights.

Take down policy

If you believe that this document breaches copyright please view our takedown policy at https://edshare.gcu.ac.uk/id/eprint/5179 for details of how to contact us. 


\title{
SKILL SHORTAGE OF BRICKLAYERS IN SCOTLAND
}

\author{
Kenneth Lawani, Sarah McKenzie-Govan, Billy Hare, Fred Sherratt and Iain Cameron
}

\begin{abstract}
Purpose - This study identifies that bricklaying trade has not benefited much from off-site production, and bricklaying has been highlighted as a trade significantly affected by the documented skills shortage in Scotland with $66 \%$ of small and medium enterprises reporting difficulties in recruiting bricklayers.

Design/methodology/approach - This study used an interpretivistic philosophy adopting the phenomenological qualitative research approach using purposeful sampling technique and semi-structured interviews to allow for emergent themes to develop. The theory of proximal similarity that connects the study's characteristics and the characteristics of the group under study was adopted.
\end{abstract}

Findings - Findings from the emergent themes identified issues grouped into key themes such as inconsistency of income, lack of care and self-employed workforce. The sub-themes included the Scottish climate, risk and profit, physical strain and government expectations and the cost of innovation. These were considered in relation to their existing and future implications for the industry.

Research limitations/implications - A wider and more diverse group of industry participants from different parts of Scotland would have made the study more representative.

Practical implications - It is imperative that the Scottish construction industry supports, develops and trains future bricklayers capable of maintaining existing housing stock and to deliver on future construction projects in Scotland.

Originality/value - This study explores the shortage of skilled bricklayers within the Scottish construction sector.

Keywords Skill shortage, Bricklayers, Scotland

Paper type Research paper

\section{INTRODUCTION}

The shortage of skilled construction workers in Scotland and most especially the shortfall of bricklayers, has been highlighted as an area of major concern for the house building sector (Abraham 2015; CITB 2017b; Escamilla et al, 2016; Farmer 2016; Sweet \& Smith 2017). The Scottish house building sector involves a wide range of stakeholders which include housing associations, local authorities, private house builders, developers, large contractors, and SMEs and there are specific skills shortages in relation to site skills such as bricklaying, joinery, site managers and other trades (Smith 2019). There are areas considered as regional hot spots with specific acute shortages in key on-site skills supply such as the Highlands and South East (SE) Scotland. The UK Government sponsored Farmer Review predicted a decline of $20-25 \%$ in the available UK workforce over the next 10 years (Farmer 2016), whilst a study undertaken by The Construction Industry Training Board (CITB 2017b) found that 43\% of construction firms have rejected projects due to the lack of skilled workers with almost $50 \%$ experiencing difficulties in recruiting the right workers. There are ongoing skills shortages in the new build 
sector and bricklaying trade has been identified as amongst the top, with a shortage of 300 bricklayers in SE Scotland (Smith 2019). This shortage has been identified to have significant impact in the new homes that will be required in SE Scotland, with the prediction that 1in 4 or 1 in 3 new homes will be built in this area from 2019-2039 (Smith 2018; 2019). Considering the future impact, this study largely focuses on the skills shortage of bricklayers. With these statistics, it is obvious that the current Coronavirus (COVID-19) pandemic would further exacerbate the already existing bricklayer skills shortage. Geographical location and mobility is also an influential factor in the composition of the available construction industry workforce, particularly within the bricklaying trade, as it is heavily reliant on the availability of local skilled manpower (Mills \& Smith 2012), and this lack of manpower results in the inability of construction firms to cope with workload (Olomolaiye 1990). Furthermore, Scotland's low population growth of $0.3 \%$ compared with $0.7 \%$ for the rest of the UK impacts on the development of local skilled construction workforce that meet the needs of the industry (CITB 2017b).

It is generally assumed that innovation is fundamental to achieving higher productivity levels within the construction industry and MacKenzie et al, (2000) identified that innovations and technologies can lead to labour savings. However, the bricklaying trade has not benefitted much from off-site production, neither has it changed significantly in the last 100 years (Dacre 2018; Farmer 2016). A large proportion of Scottish housing stock is constructed using the traditional masonry cavity-wall method of construction (Dacre 2018). In Scotland, bricklaying has been highlighted as a trade significantly affected by the documented skills shortage in the industry with $66 \%$ of Small and Medium Enterprises (SMEs) reporting difficulties in recruiting bricklayers (RICS 2018). Therefore, this study explores the shortage of skilled bricklayers within the Scottish construction industry. Skills shortage vacancies are recurring issues for employers in Scotland and the bricklaying trade is not detached from this in terms of its impact on agility, productivity and efficiency within the construction industry. The overall picture of vacancies that are hard to fill because of skills shortages in Scotland increased from $15 \%$ to $25 \%$ from 2011 to 2013 and with a slight reduction in 2015 to $24 \%$ which still makes it slightly higher than the UK average of 23\%. A cross-section of skills shortages by sector shows construction to be amongst the top five - Electricity, Gas and Water (66\%); Construction (46\%); Transport and Communications (46\%); Education (32\%); and Manufacturing (3\%) (SDS, 2017). The Construction sector experienced significant rise in the percentage of vacancies caused by skills shortages between 2013 and 2015 with Skilled Trades and Machine Operatives being impacted the most. Based on the SDS (2017) report, employers indicated that the main causes of skills shortages are as a result of lack of specialist skills or knowledge needed to perform the role; and the inability of workers to manage and prioritise their own tasks. Previous study identified the significance regarding ensuring that the skilled men remaining in the industry are retained and the need to understand what motivates them (Olomolaiye 1990). Furthermore, the impact of British exit from the European Union (EU) on jobs could further result in reducing Scotland's supply of labour and skills which would significantly impact on skills shortages (SDS, 2017).

The Scottish construction industry currently suffers from skills supply shortages and with an ever increasing demand for new homes to be built, additional training support for new entrants and upskilling existing workers is required for offsite and onsite work (Smith 2019). This resonates with the study conducted in the 1990s that identified that the traditional apprenticeship scheme has fallen too low to meet the requirements (Olomolaiye 1990), and the idea of multiskilling is a strategy that has been suggested for addressing these issues by effectively utilising existing labour pool (Ejohwomu et al., 2006). There are some expectations 
that over the next decade in Scotland, key stakeholders would be required to invest heavily in skills supply and upskilling in both private and public sector to meet these demands. Currently, the bricklaying trade is specifically experiencing skills shortages in the new build sector primarily in relation to site skills and the house builders and contractors tend to operate with a more mobile workforce to tackle the skills shortages (CITB 2018; Smith 2019). Although this is seen as a short-term fix to a long-term problem, the impact of this mobile workforce is normally felt in terms of costs, productivity, project overall performance (Ceric \& Ivic 2020) completion and handover, and increased skills supply pressures on other regions of Scotland where the workforce is drawn from. It is imperative that the construction industry looks beyond short-term fixes in order to stop the "boom-bust" cycle which is often experienced within this sector (Farmer, 2016). The aim of this study is to explore the skills shortage of bricklayers in the Scottish construction industry through the lens of workers that are involved in the trade. This includes exploring the attractions to the trade and the available support mechanisms in place for bricklayers in Scotland.

\section{FACTORS AFFECTING SHORTAGE OF SKILLED BRICKLAYERS}

\section{Recruitment of school leavers}

A number of underlying factors have been highlighted as affecting school leavers' progression into the bricklaying trade such as the negative image; the lack of career guidance; the influence of caregivers; the socio-economic impacts and the lack of social outreach programs (Agapiou et al, 1995; Bennett et al, 2013; Farmer 2016; Howard et al, 2015). It has been demonstrated that a variety of factors influence career aspirations such as parent's occupation, maternal employment, television role models, gender-role stereotypes, socio-economic status, quality of attachment relationships, agentic characteristics and distribution of power within the parental bond, and all these play significant role in future career decisions (Howard et al, 2015). Socioenvironmental factors such as media and personal contacts have also been identified as strong influencer of a young person's perception of an occupation (Agapiou et al, 1995; CITB 2017a; Escamilla et al, 2016). When all these are considered together, there is considerable scope for dissonance between school leavers' ambitions and the relative attractiveness of bricklaying as a potential career path, and this can potentially lead to lack of new entrants to the trade. Without sufficient recruitment and retention of bricklayers in the industry, and without opportunities for new entrants to upskill in terms of new methods, technologies and systems; this can further limit the number of new homes that can be built in Scotland (Smith 2019). Furthermore, teachers, pupils and parents of school leavers and the wider society need to be aware of the potential earning power on offer for skilled crafts, including the transition towards offsite and clean technologies that are currently being adopted in parts of the industry to enable them make informed choices.

\section{Apprenticeships \& training}

Apprenticeship scheme is a system of training that is regulated by law which combines workbased training with work experience to develop skills and competence whilst undertaking a paid employment with formal in-work training, mentoring and career development (Jacobson 2015; Smith 2019). The construction sector is a recipient of some of the largest apprenticeship scheme and skills investment compared to other industry sectors (SDS 2018). Considering the number of Scottish construction workers that will retire over the next 10 years and the scale of future growth in housing supply, there are deliberations that the construction sector will need more apprenticeship and training investment from government to meet the proposed housing targets in Scotland. SME companies in Scotland that are aligned to construction and 
housebuilding tend to provide critical delivery route for the construction of new housing and skills supply (Smith 2019). Apprenticeship schemes have the potential to increase bricklayer numbers, but some construction firms and SMEs in particular have limited financial resources and capability to facilitate training and skill development (Abdel-Wahab 2012; Anderson 2012; Cappelli 2015). The Scottish Government however, reported in 2016/17 that they achieved their apprenticeship targets by recruiting 26,262 modern apprentices, of which $23 \%(6,040$ on average) were within the construction industry (SDS, 2017). Generally, the construction apprenticeships in Scotland are considered to be relatively successful but SMEs are rather reluctant or unable to employ bricklaying apprentices due to barriers such as financial expense, the required investment of time, the lack of financial incentive(s), the lack of suitable and motivated individuals, the potential for skill poaching and 'free riders', the burden associated with the administrative work related to apprenticeships and the lack of locally available and relevant courses (Abdel-Wahab et al, 2008; Anderson 2012; Agapiou \& Dauber 2001). The demand for apprenticeships greatly exceeds the number of places that are available, resulting in a relatively small proportion of construction firms supporting the development of skills through the inclusion of such placements (Abdel-Wahab 2012). That means any development of the bricklaying course would have to be aligned to house building and the needs of the industry; and adapted to include a range of diverse activities and technologies that the sector will require to undertake its activities over a long term. There are suggestions that SMEs often focus solely on short-term solutions for skills shortages rather than investing in long-term resolutions (Abdel- Wahab, 2012; Anderson, 2012; Cappelli, 2015). Therefore, apprenticeship programs that focuses on short-term key pressure skills needs for house builders that addresses both regional variations in skill needs and future demands in Scotland could benefit the industry medium to longer term. Furthermore, the average working age of bricklayers approaching their retirement is high in Scotland and it is therefore important that there is sufficient room for new entrants into this role to address some of the industry limitations and other personal factors around deficit in bricklayers, painters \& decorators and plasterers entering into apprenticeship training programmes (Smith 2019; Akomah et al. 2020).

\section{Staff retention}

The needs of the construction industry are changing and some companies would rather increase their direct employment and investment in skills to allow them reduce the burden of overreliance on sub-contractors. Prior to Covid-19 pandemic, new housing supply contributed about $25 \%$ of the construction industry activity and generated about $£ 5$ bn per year to the Scottish economy with over 31,000 direct jobs and about 22,000 indirect jobs (HfS 2016). The recruitment and retention of bricklayers inevitably vary due to the degree to which the bricklaying skills exist or are in abundant supply, and this depends on the nature of different demands in the construction labour market. For example, employers tend to increase remunerations so that qualified applicants are attracted to positions during periods of skills shortage. Any form of skills shortages in available labour supply have the potential to create inflationary pressures on salaries and site operating costs (Smith 2019), and a summary of the variables that influences the supply and demand of construction and building services skills has been conceptualised by Ejohwomu et al., (2005). However, as the available labour force grows, wages are correspondingly reduced (Cappelli 2015). Due to the competitive nature of the construction industry, many contractors often offer reduced profit margins in order to win contracts whilst trying to maintain positive cash flow (Kim \& Philips 2010; RICS 2018). This can result in operatives moving between firms or out of the construction industry in search of better opportunities or a sense of worth (Kim \& Philips 2010). Similarly, the concept of 'poach and pay' of bricklayers has been identified as a major barrier to investment in training and 
skills development (Cappelli 2015; Healy et al, 2015) which ultimately, has adverse consequences for employers in terms of retaining the bricklayers. Short courses or upskilling qualifications in bricklaying capable of providing opportunities for future career progression and wider employment opportunities could potentially support inclusive growth and faster entry to work opportunities which might strengthen retention. Furthermore, offsite manufacturing methodology which shifts majority of the component build operations from onsite setting to a more controlled offsite assembly environment could be more attractive for some to consider entering the construction sector thereby diversifying the workforce (Smith 2019). Issues related to the potential earning power of bricklayers and how this is reflected on the job roles and future opportunities for growth could serve as incentives for recruitment and retention in the industry.

\section{Self-employment}

The labour market consistently undergo changes and workers are adopting innovative ways of working and issues of self-employment are currently different from the norm. Some workers prefer being self-employed because of the autonomy and structure over their working patterns and also the need for variability and choices (Taylor et al., 2017). However, the UK construction industry is considered to have a uniquely high level of bogus self-employed construction workers solely for the purpose of evading tax and insurance costs of directemployment, (Behling \& Harvey 2015; Taylor et al., 2017). These false form of selfemployment common in manual operations (e.g. bricklaying) do not involve tendering for different contracts, neither does it involve negotiating prices for services with clients or employing workers in addition to, or in place of, themselves. A common indicator of such false self-employment include long-term continuous engagement on projects with a single employer over many contracts, inability to control specific working times, not supplying plant or materials, and adhering to instructions in daily routines (Behling \& Harvey, 2015). This act of self-employment could potentially have negative impact on apprenticeship schemes and retention of vital skills due to deficiency of investment in such skills. Similarly, the seasonal nature of construction work and the cyclical economic demand of skills involving craft trades and unskilled workers makes self-employment become a legal form of engagement of labour planned to match contractual or seasonal fluctuations in demand. The UK economy is considered to suffer from this exceptionally high level of self-employment (about $40 \%$ of construction workers) in the construction industry and is amongst some of the reasons why the industry has developed less significantly when compared to countries like Germany and Spain (Behling \& Harvey, 2015). There is a high proportion of Scottish bricklayers getting close to their pension age (Cappelli 2015) and skills deficit within the bricklaying trade is a very visible manifestation of the low investment in training within the constructions sector. The perception of self-interest and self-employment of bricklayers by companies further influences why a high proportion of firms within the Scottish bricklaying trade and house building are reluctant to commit towards taking on the responsibility of training (Abdel-Wahab 2012). This further emphasises the notion that the UK construction industry has a "dysfunctional training model" and fragmented governance (Farmer 2016; Sweet \& Smith, 2017). Therefore, addressing the issue of bricklayers' self-employment could bring about a review of investment in training, alongside a development in human capital as companies are reluctant to invest in any form of training that will not lead to retention of skills. This could positively influence the "poach and pay" model currently adopted in Scotland's construction sector, and the undesirable effect associated with self-employment (Cappelli 2015; Healy et al, 2015). 


\section{METHOD}

This study explores bricklayer skills shortage within the Scottish construction sector from the lens of participants employed in the industry. It adopted an interpretivistic philosophy using the phenomenological qualitative research approach (Saunders et al, 2009; Creswell 2013; Kalpita 2017), by drawing on real-life experiences of Scottish bricklayers. The phenomenological interpretive approach is to analytically disclose the meaning-making practices of the participants, and to demonstrate how those practices generate observable outcomes (Saunders et al, 2009; Kalpita 2017; Creswell \& Creswell 2018). This approach allows the researcher to connect to the phenomena under investigation and it requires careful investigation because it is dependent more on the subjective knowledge of the participants (Saunders et al, 2009; Creswell \& Creswell 2018; Creswell \& Poth 2017). The phenomenological approach was considered suitable because it is useful in describing lived experiences of the participants through interviews and it allows the researcher to make sense of the phenomenon of bricklayer skills shortage (Creswell 2013). An inductive research approach was adopted based on the ability to collect rich data (Saunders et al, 2009; Creswell $\&$ Poth 2017). This approach enabled the investigation of this phenomenon by allowing participants express their perceptions of the bricklaying skills shortage and its consequences for the Scottish construction industry. The principle of proximal similarity indicates that no two settings are exactly equivalent when multiple factors are taken into consideration during a study (Brunner, 1987). Therefore, this study furthermore considered individual differences regarding the study design and participants, despite the desire to be able to replicate and other homogeneous factors. Adopting this principle is also contingent upon other attributes of the participants, e.g. years of experience and the participant status within their workplace.

\section{Sample}

A purposive non-probability sampling technique of the target population was adopted by engaging participants willing to share their lived experiences on the issue of bricklaying skills shortage in Scotland (Creswell \& Creswell 2018; Creswell \& Poth 2017). Access to study participants was facilitated by industry contacts within the Scottish construction sector. The qualitative study involved 14 (male) participants all based in Scotland. These participants have varying years of construction industry and bricklaying experience, involved in different types of jobs, have undertaken different roles within multiple organisations in Scotland and are from different geographic locations; see Table 1 for participant information. Participation in this study was voluntary, and it followed institutional ethical procedures and GDPR protocols.

\section{Method of Data Collection}

The information collected for this study was based on the perception of the participants regarding the skills shortage of bricklayers within the Scottish construction sector. The process of data collection was through semi-structured open-ended interviews. This was the most appropriate approach that facilitated the acquisition of useful information on bricklaying skills shortage by allowing the issue to be explored more in-depth through the lens of the participants. The semi-structured interview was exclusively dependent on the availability of the participants, the time constraints regarding their workplace productivity requirements and their geographical locations. Five participants living outside close geographical proximity ( $>40$ miles from the location of the researcher) were interviewed over the phone, while nine participants were faceto-face and all the interviews were audio-recorded. 
Table 1. Participant Information

\begin{tabular}{|c|c|c|c|}
\hline Code & Work Role & $\begin{array}{l}\text { Age } \\
\text { Range }\end{array}$ & Background \\
\hline INT1 & Director of a construction company & $30-35$ & A bricklayer since age 15 \\
\hline INT2 & Bricklayer (Foreman) & $45-50$ & A bricklayer since age 16 \\
\hline INT3 & Bricklayer & $40-45$ & Labourer at age 16 before becoming a bricklayer \\
\hline INT4 & Bricklayer (Foreman) & $40-45$ & A bricklayer since age 16 \\
\hline INT5 & Bricklayer & $45-50$ & A bricklayer since age 16 \\
\hline INT6 & Bricklayer apprentice & $20-25$ & $4^{\text {th }}$ year bricklaying apprentice \\
\hline INT7 & Bricklayer apprentice & $20-25$ & $4^{\text {th }}$ year bricklaying apprentice \\
\hline INT8 & $\begin{array}{l}\text { Apprenticeship officer Construction Industry } \\
\text { Training Board (CITB) }\end{array}$ & $50-55$ & A bricklayer since age 16 \\
\hline INT9 & Director of bricklaying firm & $55-60$ & $\begin{array}{l}\text { Quantity Surveyor now runs a bricklaying sub- } \\
\text { contracting firm }\end{array}$ \\
\hline INT10 & Bricklaying sub-contractor & $45-50$ & A bricklayer since age 16 \\
\hline INT11 & Bricklaying sub-contractor & $30-35$ & $\begin{array}{l}\text { Degree in Building Surveying then took over } \\
\text { family bricklaying business }\end{array}$ \\
\hline INT12 & Bricklayer & $35-40$ & Bricklayer since age 16 \\
\hline INT13 & Bricklayer (Foreman) & $30-35$ & Bricklayer since age 16 \\
\hline INT14 & Site Manager & $50-55$ & Bricklayer since age 16 \\
\hline
\end{tabular}

Previous studies have indicated that the use of telephone interviews have no negative impact on the quality of data generated (Rosenthal 2016). The use of semi-structured interviews allowed for emergent themes to be developed without making the data collection process firmly prescriptive. Minor adjustments were incorporated in the course of the interview process - for example, some questions were readapted to suit different situations if the participants provide answers to such questions before being asked or by asking them to offer more clarity or give examples. The questions employed were non-leading to mitigate against interviewer bias (Rosenthal 2016), and the questions required the participants to describe their experiences and perceptions of skills shortage of bricklayers in Scotland. The interviews lasted an average of 40 minutes and after 14 interviews with participants from 10 different companies across Scotland were conducted, no new information was being generated so the data collection process was discontinued (Creswell \& Plano Clark, 2017; Rosenthal 2016). Taking cues from the literature review, the established concepts of skills shortage in construction were used as the springboard for developing the study questions with emphasis on bricklaying.

The questions adopted for this study include the following:

- How do you think school leavers should be attracted to bricklaying as a career? 
- Describe your opinion regarding the role of apprentices within bricklaying

- Describe what you think could be (or is being) done to support bricklayers

- Describe how you became a bricklayer

- What do you enjoy about your job?

- Describe the reasons why you think people leave the bricklaying trade.

\section{Method of Data Analysis}

The recorded interview transcripts were transcribed verbatim to provide the data for a thematic analysis. Areas of shared experiences or expertise between participants were identified, and subsequently coded to allow overlapping concepts to be highlighted through a mixture of descriptive and interpretative analysis. To improve the external validity of the study, the theory of proximal similarity that connects the study's characteristics and the characteristics of the group being studied (Brunner, 1987) was implemented based on the ways the different participants shared similar perceptions of the bricklaying trade. This includes the involvement of different groups of participants from different parts of Scotland and at different times in the study (Creswell \& Plano Clark, 2017; Rosenthal 2016). Two people independently coded the interview themes, and afterwards shared and agreed the coding which further improved the inter-reader agreement and reliability (LeVasseur, 2003).

\section{FINDINGS \& DISCUSSIONS}

The emergent themes based on the commonality of participant's responses to questions were grouped into key themes and sub-themes (Clarke \& Braun, 2017), by categorising them in relation to the existing and future bricklaying workforce in Scotland, see Tables $2 \& 3$. The dominant themes and sub-themes were identified and grouped to reflect the perceptions and understanding of the participants involved in the interviews (Nowell et al, 2017; Clarke \& Braun, 2017). The inclusion of some quotes are representative of the wider data set and analysis undertaken.

\section{IMPACT OF BRICKLAYER SHORTAGE ON THE EXISTING WORKFORCE}

\section{Inconsistency of Income}

The inconsistency in income of bricklayers were identified from the interviews as constraints affecting the ability of bricklayers to work and consequently earn some money. The issue of inconsistent earning capacity of bricklayers was alluded to by 11 participants as fundamental reasons why many individuals leave the bricklaying trade. The consensus was that the inability of bricklayers to have guaranteed work and sustained income leads to anxiety and this is further exacerbated by the "roller-coaster" nature of the construction industry. The participants indicated that the short-term high levels of pay earned by Scottish bricklayers are often offset by prolonged periods of inactivity resulting from either the adverse and unpredictable weather conditions, or inherent ill-health issues made worse by the arduous nature of the occupation which consequently results in low retention rate of bricklayers.

"If you don't lay anything you don't get paid...it's going to get to the stage where financially it's not viable to just stay in that trade" 
Table 2: Impact on the existing workforce

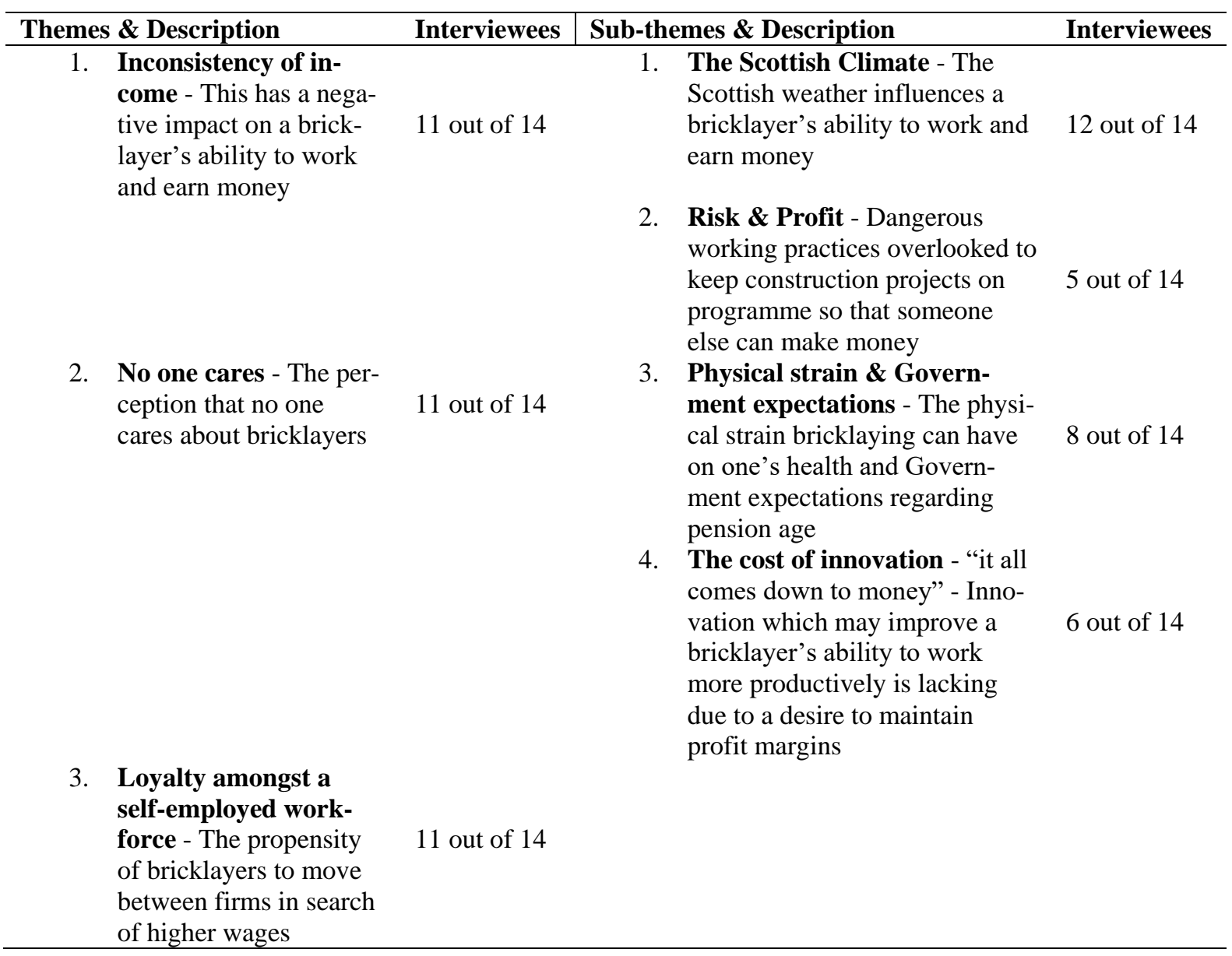

Table 3: Impact on the future workforce

\begin{tabular}{lll}
\hline Themes & Description & $\begin{array}{l}\text { Interview- } \\
\text { ees }\end{array}$ \\
\hline Getting the right candidate & $\begin{array}{l}\text { The significance of recruiting the right candidates into the } \\
\text { bricklaying trade }\end{array}$ & 7 out of 14 \\
$\begin{array}{l}\text { The viability of hands-on } \\
\text { training }\end{array}$ & $\begin{array}{l}\text { Boosting new recruits into the bricklaying trade in Scotland is } \\
\text { essential }\end{array}$ & 8 out of 14 \\
\hline
\end{tabular}

The participants overwhelmingly indicated that the inconsistent earning capacity is amongst the reasons why Scottish bricklayers frequently move between bricklaying firms or find new ways of making money or a new career path. This has an impact on the number of bricklayers quitting their careers in construction in search of alternative, more consistent and sustainable employment opportunities:

"Guys that were good bricklayers just end up taxi drivers cause there's no work out there and what happens then, it drives the prices down because everyone is vying for the one job.... people will work for anything and the contractors know that...... they let it happen" 
Previous studies indicated that projected earning capacity strongly correlates with a youngster's career aspirations (Agapiou et al, 1995; Howard et al, 2015); with many youngsters emphasising that a career in the construction industry is well paid (CITB 2017a). However, not redressing the issues around inconsistent income of bricklayers may further jeopardise the potential to recruit the most suitable candidates into this trade. The issue of recruitment and retention becomes even more dire for the bricklaying trade due to the high proportion of the Scottish bricklaying workforce that are presently getting close to their pension age (Cappelli 2015; CITB 2017a; Farmer 2016). The ways in which bricklayers are paid has an impact in the quantity and quality of training undertaken, and the participants perceive that apprenticeship programmes tend to obstruct a trainee's ability to earn, thus reducing the amount of time new recruits are offered hands-on training. This could result in the loss of key bricklaying skills. With no adequate plans put in place to increase the employment of experienced bricklayers, MacKenzie et al. (2000) indicated that issues around direct employment might alleviate this problem. The subsequent levels of attrition experienced amongst apprentice bricklayers could also be due to frustration of being unable to learn key skills in their chosen trade.

"The amount of time we have to invest in training someone up, it's not viable .... we're on price offer jobs. We get a price for the job and that's what it is, it's fixed and the faster we got off it the faster we get onto the next one and keep going then...there's no allowance for maybe 3-4 days off the job set aside for training".

\section{No one cares about us}

The perception that no one cares about bricklayers was shared by eleven of the participants interviewed. The participants agreed that bricklayers are often ill-treated and unsupported by employers or contractors. They also revealed that risky working practices are sometimes condoned to keep construction projects on programme so that contractors don't lose money. Other issues identified were related to the physical impact bricklaying can have on a worker's health (musculoskeletal disorders) and the expectations from the government regarding pension age which takes no cognizance of the health of the workers. Technological innovation which may help to improve a bricklayer's productivity, processes and ability to work more efficiently are currently not applicable to bricklaying because of the desire amongst contractors and employers to maintain or maximise high-profit margins. Innovations such as bricklaying robots could potentially allow bricklayers to move from their current labour-intensive roles to a more supervisory quality-assurance role. MacKenzie et al. (2000) identified that every other industry is investing money into developing technology that moves away from its reliance on people at certain skill levels but an element of caution is necessary because new technologies and construction techniques take both time and money to develop (Juricic et al. 2021).

\section{Loyalty amongst a self-employed workforce - "keeping hold of bricklayers"}

Eleven participants unequivocally agreed that bricklayers are motivated to move between firms in search of higher wages depending on demand. Furthermore, the issue of bricklayers being motivated by the level of pay was amongst the variables identified by Olomolaiye (1990).

"Bricklayers have no loyalty to anyone.... if someone says that job is going to pay you £2 a metre more, and you go 'can you match it', 'no'.... 'well if you can't match it then I'm going to work for someone else' and that's what they do"

The bricklayers will move to other jobs and employers with potential for higher wages. The participants associated this to the limited window of opportunity that many bricklayers have to 
earn all through their career. The participants also believe that bricklayers have their own selfinterest and the need to look after themselves as they cannot rely on anyone else. Overall, the participants agreed that the nature of the construction industry is driven by making profit (the employers), without much concern or care about the bricklayer's health or wellbeing. Participants that experienced the last years 2008 recession seem to have been influenced by how quickly the bricklayers could become unemployed in the industry, a point also addressed by MacKenzie et al, (2000). The coronavirus (COVID-19) health pandemic is presently creating the same form of anxiety regarding job losses and long-term unemployment for bricklayers in Scotland due to the imposed lockdown measures. The self-employed nature of bricklayers is a factor that significantly contributes to the incessant job/role change of bricklayers between firms. The participants indicated that the contractors show no loyalty in times of financial hardship; which sort of reinforces the concept that some employers do not value or invest in their self-employed contractors and operatives (Healy et al, 2015; Sweet \& Smith, 2017).

"Because you're a subcontractor, if there's no contract they can just let you go whenever they want to”.

\section{Sub-themes}

\section{The Scottish Climate}

Twelve participants commented on the impact and disruptions the unpredictable Scottish weather have regarding the ability of bricklayers to be gainfully employed all year round. They commented on the detrimental impact of working as a bricklayer in a country where seasonal fluctuations in climate affect when brickwork can be undertaken. They agreed that the sudden variation in rainfall levels and dip in temperature sometimes slow or stop the physical act of bricklaying on site. Although the participants emphasised the need for when brickwork can be undertaken, they all indicated that there are specific times within the year that bricklayers struggle to undertake their work due to inclement weather factors outside their control which ultimately leads to project delays and cost overruns (Ceric \& Ivic 2020).

"How many days of winter do we get $5^{0} \mathrm{C}$ solid through the day so... you know Scottish weather... that was a four-month winter there, if you didn't earn for four months, that would kill anyone"

"Bricklayers get paid a fortune because they only work about 6 months of the 12 months.... bricklayers will always tell you they're earning a grand a week in the summertime, they'll never tell you about the winter time".

Most SMEs in Scotland are involved in the traditional method of build as opposed to modular construction. Therefore, inclement weather conditions tend to cause major hindrance and delays to traditionally built projects compared to factory-based construction methods. The tighter lockdown measures during the winter months due to COVID-19 will have maximum impact on the building trade (build speed) and this further exacerbates unemployment for bricklayers in Scotland.

\section{High risk \& high profit}

Although health and safety is an important part of the daily task of bricklaying, the work programme and profit seem to be the main driver for those involved in construction projects 
according to five of the participants. Furthermore, the requirement for onsite bricklaying activity means there is lower guarantee of safety onsite compared to a controlled factory environment.

"It's all about money. It's all about getting something done as quickly as possible so they can make money"

The participants indicated that when work programmes are delayed which inevitably impact on profit; risky working practices become increasingly allowed or ignored on site. This reinforces the assumption that employers do not care about the welfare of bricklayers, but treat bricklayers simply as a means by which employers can make money (Healy et al, 2015).

"Health and safety is all good until they want the work done and then the health and safety gets booted out of touch. Right we're behind in the job, f**k it, let's go"

A return to direct employment where employers have greater involvement in craft operative training on health and safety could ultimately change these current perceptions regarding risk taking.

\section{Physical strain \& Government expectations}

Eight participants re-emphasised that bricklaying is arduous and physically demanding and the nature of the tasks undertaken by bricklayers impact their ability to work up to a certain age; substantially below the expected Scottish Government state pension age of 66 which rises to 67 by 2028 .

"Its hard work...the strain on your back, knees, elbows, you name it...it's not a trade that you look to continue into your late 50s and 60s"

The participants agreed that the state pension age set by the Scottish Government is way above what bricklayers can attain because of the physical strain and environmental demands of the job, and they consider this as further strengthening their opinions that no one cares about their wellbeing. Some of the participants acknowledged the lack of pay and support from employers regarding taking time off, coupled with the complexity of the job and anxiety about pensions makes bricklayers work as much as they can without taking time off.

"The government says that everyone should retire at 66, aye if you're sitting in a wee office for the rest of your days not under any pressure.... these guys are working hard...... you see people running down, their bodies gone, their knees, ankles, wrists, backs.... I don't want to put any more strain on my body, I don't need another few year's bricklaying to batter it more"

According to Smith (2019), it is essential to have sufficient pipeline of new entrants that will take on these roles to enable knowledge transfer and sector continuity. This could potentially address the significant shortfall in the number of bricklayers across Scotland.

\section{Cost of innovation}

Technology and innovation within the Scottish construction sector have seen some development over the last decade leading to a requirement of new types of skills in the new housing sector (Smith 2019). However, issues around lack of improvement in design or innovation of building materials, techniques and technologies specific to bricklaying could hinder productivity and wellbeing of bricklayers according to the participants. 
By facilitating such improvement, Scotland's current bricklaying workforce could have a longer working life, improved productivity and reductions in on-site delays, similar suggestions by Ceric \& Ivic (2020). The lack of innovation and adoption of new ways of working currently affects agility, efficiency and productivity. Creativity within the bricklaying trade is the most least-demand and in short supply as there is currently no prediction of the adoption of automation that could transform the skills bricklayers need. To effectively transform the bricklaying trade, it will require effective training and upskilling embedded in both private and public sector domains to allow for the close interactions required in planning, design, regulatory compliance, technical knowledge, product and system in innovations and sustainable ways of working (Smith 2019). While the adoption of new technology should be welcomed (Juricic et al. 2021), it is also imperative that operatives need to be retrained in such new innovations and this is normally not a common practice within the construction sector (MacKenzie et al. 2000). With the transformation in future demand and technologies, skills planning and innovation in the bricklaying sector will be required to meet the highest levels of productivity required to meet the projected housing demands in Scotland.

\section{Lack of support}

Most of the participants indicated that the lack of support (from employers or union) experienced by bricklayers have an impact on attrition and recruitment. The self-employed nature of bricklaying trade was perceived by participants to lack some benefits that other trades would describe as standard, e.g. pensions, sick pay and holiday pay (Healy et al, 2015; Kim \& Philips 2010). This issue is further intensified by the physically demanding nature of bricklaying. The bricklaying trade is considered to have a significant proportion of workers that are notionally self-employed (self-declaration) and companies tend to view this as a means of self-interest by bricklayers. Study around the economic benefit of home building in Scotland indicates that for every 1 home builder employee, there are about 4 sub-contractors/selfemployed workers that are employed onsite (NLP 2015). The bricklayers also believe that the clients and contractors are 'in it for themselves', compelling the bricklayer to respond in a similar fashion. Such negative attitudes may be detrimental to recruitment numbers. Although there are unions available to assist bricklayers such as the Guide of Bricklayers and Unite, none of the participants in this study mentioned if they or their firms have received any viable means of support.

Six participants remarked on failings associated with the current Government initiatives and incentives to enhance bricklaying numbers in Scotland. Three participants identified that the CITB's initiatives ignore the realities of bricklaying and actually dissuade firms from providing apprenticeship programmes. There was a consensus amongst those employed within smaller bricklaying firms regarding the level of impact government initiatives have on the growth of bricklayer numbers:

“We do an apprentice program but we're only a small company so we're not going to change the world".

However, if firms receive some form of incentive from the Government and the Construction Industry Training Board to train apprentices and support to employ these trainees, this could potentially increase the number of bricklayers in Scotland. There have been discussions regarding skills courses developed to align to house building needs where there are specific shortages to offer faster entry to work (e.g. bricklaying for house building), but this would 
require further future top up in training, development and assessment prior to reaching full modern apprenticeship qualification (Smith 2019). Furthermore, industry bodies raised a number of issues that such a route towards a qualification for bricklaying for house building should be directly sponsored and supported by an employer, which employers consider as the lack of support.

\section{IMPACT OF BRICKLAYER SHORTAGE ON THE FUTURE WORKFORCE}

Participants identified the significance of recruiting the right apprentice bricklayers. The common theme indicated that employing the right apprentice empowers companies to find long-term solutions to the tacit knowledge and challenges that comes with the bricklaying trade, including the financial benefits, pride in the work and grasp of the trade associated with the career for the trainee. However, the participants also agreed that some trainees enter into apprenticeship programmes with unrealistic expectations concerning the bricklaying trade; while others choose the bricklaying apprentice as a last career option.

"If the teachers are standing in the college and going 'that boy's not even remotely interested', right he's standing in a warm, dry, clean environment and he's not the slightest bit interested, so what's he going to be like on a winters day out there.... what are we supposed to do with them"?

The participants commented that some apprentices have the wrong attitude or show a lack of interest in the acquisition of the bricklaying skill; while the participants that are employers remarked that in some instances they felt trapped within the apprenticeship scheme based on the reluctance of some trainees to learn, commit and engage with the job. Abdel-Wahab (2012) and Anderson (2012) identified the shortfall of available apprenticeship placements with the concerns regarding the levels of support offered by bricklaying firms throughout Scotland. Also, there are indications that any such course would have to be aligned to career progression, contributing towards qualification for a full modern apprenticeship and there would have to be evidence of industry demand (Smith 2019). Two of the participants indicated that the role of the apprentice is held in higher regard than that of their own employees, and employers lack the power to reprimand or terminate apprenticeship employment contracts even when the apprentice is underperforming. The work ethic and attitudes of the apprentices could potentially influence the level of training (Cappelli 2015), which could be the case for bricklaying trade in Scotland:

"Everyone in this day and age wants to have a job, there's no point diving in and just being a bricklayer because you can't get a job, I don't believe that is the making of a bricklayer. All you're going to do is take on a job, you're not going to be interested, you're not going to be good at it, and you're just going to give guys like me on site grief and you're no good to me, so I'm just going to bang you down the line".

Three participants indicated that the support offered by CITB concerning apprenticeship placements was too standardised and fail to take into account the realities of finding the best candidate. They referred to the nature of the profession and the high proportion of time spent working outside which is fundamental; but instead simply follow a set of prescribed rules.

"I went to CITB, I said this guy is good can we help him out, he's taken to this really well, we'll put more money into it, can you help out and they said no, the way it's structured is what it is. I said look the guy's wife can't work, he's got a young kid, you 
This approach has further worsened the construction industry's existing tendencies to underinvest in the development of skills and provision of training (Anderson 2012). Although the concept of simulated workplace environments can off-set some of the restrictions placed on training because of variations and the unpredictable winter weather conditions in Scotland, it may lead to higher attrition rates post-apprenticeship as the reality of a Scottish working environment would very rapidly become real on construction sites to new apprentices (AbdelWahab 2012; Anderson 2012).

\section{CONCLUSION}

The construction of new homes in Scotland will continue to increase significantly over the next decade and skills shortage within the wider construction sector places more pressure on the ability of SMEs and larger construction companies to meet the housing targets. Some house builders have reported interruptions on project sites due to delays related to skills shortage, and the industry should be looking towards moving to more offsite settings where practicable. This study which focuses on the lived experience of participants with bricklaying skills including owners of bricklaying firms identified that the inconsistency in the earning power of experienced bricklayers in Scotland is suggested as amongst other factors influencing the current skills shortage in a number of ways. The inconsistent earning capacity of bricklayers often lead to experienced workers leaving the trade in search of a job with more reliable and consistent income. This have an impact on the ability to recruit and increase the number of school leavers keen to train as bricklayers. A review of the payment terms currently based on a metred-rate to one that is based on weekly or monthly remuneration contingent on the employer or terms of contract may further help to resolve the inconsistent income across the industry. Furthermore, the ability of construction firms to provide consistent salaried earnings to bricklayers within the Scottish context would require long-term financial planning, alongside innovative working practices that would benefit both the workers and firms across Scotland.

The idea that employers do not care about the welfare or wellbeing of bricklayers is an issue that resonates with the self-employed across different industries. Issues around unsafe practices and workers taking unnecessary risks in the process of getting their jobs done; unpaid time off due to ill health; lack of holiday pay; lack of innovation and lack of job security are some aspects that needs to be redressed within the industry. The cost of innovation and adoption of new technologies which could bring significant changes to construction have major cost implications on the overall turnover for most employers and the construction industry generally have low levels of investment in innovation. It is also evident that bricklayers have no loyalty to their employers when remuneration is involved as they often have the tendency to quit a contract or leave an employer when offered a better wage by another firm. The rationale for such low retention and high geographic labour mobility relates to what bricklayers perceive as a limited or short career lifespan compared to other trades regarding earning potentials. Resolving some of these issues require a sense of engagement fostered within the bricklaying population, and a shared purpose by ensuring that those legitimately employed in this trade are given a voice. Furthermore, a move away from bogus self-employment could help facilitate such a change, whilst supporting the provision of apprenticeship schemes and placement opportunities.

The unpredictable Scottish weather affects the performance, productivity and earning power of bricklayers and the time required to accomplish their tasks. These seasonal fluctuations thus 
impact on the practicality to undertake brickwork all year round and offsite construction could potentially mitigate such disruptions experienced on-site. The weather furthermore impedes the ability of apprentices to undertake their role and get involved with on-site training. Therefore, the adoption of simulated work environment that enables apprentices to undertake indoor trainings could be a viable solution that might increase uptake and lower attrition rate. With the availability of different construction materials on the market, there is a tendency that house builders may start to adopt alternative and different systems of build that are not weather bound like brick and blockwork. The ability to manage workplace risks and risk assess the task being undertaken is an essential part of bricklaying trade. Also, many bricklayers do not see the significance of undertaking an apprenticeship scheme or a prescribed training to qualify as a bricklayer because progression is informal through site experience. Bricklayers are more generally employed by either a bricklaying firm or by labour-only subcontractors rather than the regular house builders or contractors, and this is due to the self-employed status of most bricklayers. Some Scottish construction firms have shifted from direct labour to indirect employment and labour-only contracting and this could be a breeding ground for risk taking due to price work. There are also suggestions that getting the work programme on schedule is the ultimate goal because it impacts on profit. This encourages risk taking and short-cuts, and there is currently no technology being adopted to improve a bricklayer's safety and productivity.

Construction work is considered as physically demanding and it impacts on the ability of most trades men working up to the government retirement age. The Scottish Government capital budget for housing is described as the biggest house building push in a generation and the bricklaying workforce required to achieve these targets are currently not in place. However, the provision of available funding for apprenticeship schemes that promotes and attracts youngsters into bricklaying trade, if revisited, could bridge the current and future house building needs in Scotland. Even with the Government drive on increasing apprenticeship numbers, the construction sector still has the highest proportion of apprentices being made redundant and with low retention rates which thus impacts the success of apprenticeship programmes. The scope of work for a bricklayer is mainly restricted to laying bricks and there is typically a separation between manual and intellectual functions on sites, with activities such as setting out, reading drawings, planning, monitoring and delivering the work executed by site managers, site engineers or supervisors. However, a bricklayer could be employed in a series of different jobs as trades foreman, drain layer and concreter, each involving an array of tasks, for instance, setting out, the actual laying of bricks or blocks, mixing mortar, and snagging work. It is imperative that the Scottish construction industry, government, CITB and other agencies support and sustainably develop and train future bricklayers to enable the maintenance of existing housing stock and to meet the needs of future construction projects. This could potentially enhance the Scottish government drive towards achieving its ambitious housing targets.

Although it is extremely important to attract young talents that are recruited and trained in the bricklaying trade, the industry would need to devise a clearer roadmap of the future career pathways available. In the current scenario, bricklaying is considered as a trade under pressure, and there is relatively low level and narrow scope for change in terms of associated qualification. To attract the interest of young school leavers into this trade, time and capital investment that would inspire them to see a future in bricklaying would help them make informed decisions. There should be a review and an overhaul of the standardised funding currently in place for the bricklayer apprenticeship scheme. There is need for meaningful collaboration between bricklaying firms and schools by incorporating hands-on trade skills 
within the school curriculum and pre-apprenticeship programmes to encourage and nurture the right candidate. This could potentially support the growth of bricklayer numbers within the Scottish construction industry otherwise there will be ongoing difficulty in retaining the current talents, knowledge and expertise of the present bricklayers.

Data availability statement: All data, models, and code generated or used during the study appear in the submitted article.

\section{REFERENCES}

Abdel-Wahab, M., Dainty, A., Ison, S., Bowen, P., Hazlehurst, G., 2008. Trends of skills and productivity in the UK construction industry. Journal of Engineering, Construction and Architectural Management; 15(4), 372-382: https://doi.org/10.1108/09699980810886865

Abdel-Wahab, M., 2012. Rethinking apprenticeship training in the British construction industry. Journal of Vocational Education \& Training; 64(2), 145-154:

https://doi.org/10.1080/13636820.2011.622450

Abraham, K., 2015. Is skill mismatch impeding U.S. economic recovery? ILR Review. 68(2), 291-313: https://doi.org/10.1177/0019793914564962

Agapiou, A., Price, A. \& Mccaffer, R., 1995. Forecasting the supply of construction skills in the UK. Journal of Construction Management and Economics. 13(4), 353-364:

https://doi.org/10.1080/01446199500000039

Agapiou, A. \& Dauber, V., 2001. Changing skill needs and training requirements in the Scottish construction industry. RICS. Construction and building research conference (COBRA). Glasgow: 2001, 1-12. London: RICS.

Akomah, B. B., Ahinaquah, L. K., \& Mustapha, Z., 2020. Skilled labour shortage in the building construction industry within the central region. Baltic Journal of Real Estate Economics and Construction Management; 8, 83-92; https://doi.org/10.2478/bjreecm-2020$\underline{0006}$

Anderson, P., 2012. Plus c'est la meme chose: joinery apprenticeship arrangements in Scotland. Journal of Education and Work. 27(2), 137-160:

https://doi.org/10.1080/13639080.2012.726965

Behling, F. \& Harvey, M., 2015. The evolution of false self-employment in the British construction industry: a neoPolanyian account of labour market formation; Work, employment and society. Vol. 29(6) 969-988; DOI: 10.1177/0950017014559960

Bennett, J., Lubben, F. \& Hampden-Thompson, G., 2013. Schools that make a difference to post-compulsory uptake of physical science subjects: some comparative case studies in England. International Journal of Science Education. 34(4), 663-689: https://doi.org/10.1080/09500693.2011.641131

Brunner, R. D.,1987. 'The Principle of Proximal Similarity', Knowledge, 9(1), pp. 145-160. doi: $10.1177 / 107554708700900106$

Cappelli, P., 2015. Skill gaps, skill shortages and skill mismatch: evidence and arguments for the United States. ILR Review. 68(2), 251-290: https://doi.org/10.1177/0019793914564961 
Ceric, A., \& Ivic, I., 2020. Construction labor and skill shortages in Croatia: causes and response strategies. Organization, Technology and Management in Construction; 11: 22322244; https://doi.org/10.2478/otmcj-2020-0019

Clarke, V., \& Braun, V., 2017. Thematic analysis. The Journal of Positive Psychology, 12(3), 297-298. https://doi.org/10.1080/17439760.2016.1262613

Construction Industry Training Board, 2017a. Changing perceptions: the growing appeal of a career in construction. Birmingham: CITB.

Construction Industry Training Board, 2017b. CITB Research - Industry Insights Construction Skills Network Forecasts 2017-2021, Scotland. Birmingham: CITB.

Construction Industry Training Board, 2018. Local Construction Skills Needs for Scotland. Birmingham: CITB.

Creswell, J., 2013. Qualitative Inquiry \& Research Design - Choosing Among Five Approaches. $3^{\text {rd }}$ Edition. London: Sage.

Creswell, J. W., \& Creswell, J. D., 2018. Research Design: Qualitative, Quantitative and Mixed Methods Approaches, 5th Edition, Thousand Oaks, CA: SAGE Publications, Inc.

Creswell, J. W., \& Plano Clark, V. L., 2017. Designing and Conducting Mixed Methods Research, 3rd edn. Sage Thousand Oaks, CA, USA.

Creswell J. W., \& Poth, C. N., 2017. Qualitative Inquiry and Research design: Choosing among Five Approaches, 4th edn. Sage Thousand Oaks, CA, USA.

Dacre, I., 2018. Construction cost comparison report - affordable housing, Timber \& Masonry. Bristol: Rider Levett Bucknall.

Ejohwomu, O. A., Proverbs, D. G. \& Olomolaiye, P., 2005. Modelling the supply and demand for construction and building services in the Black Country. In 5th International Postgraduate Research Conference in the Built and Human Environment. Salford, pp. 116123.

Ejohwomu, O., Proverbs, D. G. \& Olomolaiye, P., 2006. Multiskilling: A UK construction and building services perspective. In D Boyd (ed.), Twenty-second annual conference 2006, September 4-6, UCE, Birmingham. ARCOM, Reading, pp. 885-894.

Escamilla, E., Ostadalimakhmalbaf, M. \& Bigelow, B., 2016. Factors Impacting Hispanic High School Students and How to Best Reach Them for the Careers in the Construction Industry. International Journal of Construction Education and Research. 12(2), 82-98: https://doi.org/10.1080/15578771.2015.1077296

Farmer, M., 2016. The farmer review of the UK construction labour model-modernise or die [online]. London: Construction Leadership Council.

Healy, J., Mavromaras, K. \& Sloane, P., 2015. Adjusting to skill shortages in Australian SMEs. Applied Economics. 47(24), 2470-2487:

https://doi.org/10.1080/00036846.2015.1008764 
HfS Report., 2016. The Economic \& Social Benefits of Home Building in Scotland. Homes for Scotland.

Ho, P. H. K., 2016. Labour and skill shortages in Hong Kong's construction industry. Engineering, Construction and Architectural Management, Vol. 23 No. 4, 533-550

Howard, K., Flanagan, S., Castine, E. \& Walsh, M., 2015. Perceived influences on the career choices of children and youth: an exploratory study. International Journal for Educational and Vocational Guidance, 15(2), 99-111: https://doi.org/10.1007/s10775-015-9298-2

Jacobson, P. (2015). Reinvigorating VET: Best Practice in Trade Apprenticeships. International Specialised Skills Institute Fellowship report, International Specialised Skills Institute, Carlton, viewed 18 October 2020; https://www.issinstitute.org.au/wpcontent/uploads/2015/11/Report-Jacobson-Final-LowRes.pdf

Juricic, B.B., Galic, M., Marenjak, S., 2021. Review of the Construction Labour Demand and Shortages in the EU. Buildings, 11(1), 17; https://doi.org/10.3390/buildings11010017

Kalpita, P., 2017. Introducing Interpretive Approach of Phenomenological Research Methodology in Environmental Philosophy: A Mode of Engaged Philosophy in the Anthropocene. International Journal of Qualitative Methods. 16(1), 1-10: https://doi.org/10.1177/1609406917724916

Kim, J. \& Philips, P., 2010. Health Insurance and Worker Retention in the Construction Industry. Journal of Labour Research, 31(20): 20-38, https://doi.org/10.1007/s12122-0109083-4

LeVasseur, Jeanne J., 2003. The Problem of Bracketing in Phenomenology. Qualitative Health Research, 13(3), 408-420, Sage Publications: DOI: 10.1177/1049732302250337

MacKenzie, S., Kilpatrick, A. R., \& Akintoye, A., 2000. UK construction skills shortage response strategies and an analysis of industry perceptions, Construction Management and Economics, 18:7, 853-862, DOI: 10.1080/014461900433131

Mills, A. \& Smith, J., 2012. Barriers to the development of SME's in the Australian construction industry. The Australian journal of construction economics and building, 2(2) 71 - 79: https://doi.org/10.5130/AJCEB.v2i2.2902

Nathaniel Lichfield \& Partners 2015. The Economic and Social Benefits of Home Building in Scotland

Nowell LS, Norris JM, White DE, Moules NJ., 2017. Thematic Analysis: Striving to Meet the Trustworthiness Criteria. International Journal of Qualitative Methods, 16, 1-13 doi: $\underline{10.1177 / 1609406917733847}$

Olomolaiye, P. O., 1990. An evaluation of the relationship between bricklayers' motivation and productivity. Construction Management \& Economics, 8, 301-313

Rosenthal, M., 2016. Qualitative research methods: Why, when, and how to conduct interviews and focus groups in pharmacy research. Currents in Pharmacy Teaching \& Learning, 8(4), 509-516: https://doi.org/10.1016/j.cptl.2016.03.021 
Royal Institute of Chartered Surveyors, 2018. Workloads remain resilient despite near-term volatility in output. London: RICS.

Saunders, M., Lewis, P. \& Thornhill, A., 2009. Research methods for business students, $5^{\text {th }}$ Edition. Essex: Pearson Education Limited.

Skills Development Scotland (SDS), 2017. Modern Apprenticeship Statistics. Glasgow: Skill Development Scotland: https://www.skillsdevelopmentscotland.co.uk/media/43282/modernapprenticeship-statistics-quarter-4-2016-17.pdf

SDS Quarterly Report., 2018. Modern Apprenticeships statistics: Quarter 3, 2017-18. Skills Development Scotland.

Smith, S., 2019. New Housing \& Future Construction Skills - Adapting and Modernising for Growth, Scottish Government

Smith, S., 2018. Presentation to SLWG. Future Housing Requirements and Skills Needs for South East Scotland. Institute for Sustainable Construction, Edinburgh Napier University.

Sweet, R. \& Smith, D., 2017. Will China build tomorrow's Britain? Examining the impacts of Brexit and the skills crisis. Journal of Construction Research and Innovation, 8(1), 2-12: https://doi.org/10.1080/20450249.2017.1313507

Taylor, M., Marsh, G., Nicol, D. \& Broadbent, P., 2017. Good Work: The Taylor Review of Modern Working Practices;

https://assets.publishing.service.gov.uk/government/uploads/system/uploads/attachment_data /file/627671/good-work-taylor-review-modern-working-practices-rg.pdf 